\title{
THE ONSET OF PSORIASIS DURING THE TREATMENT OF INFLAMMATORY BOWEL DISEASES WITH INFLIXIMAB: should biological therapy be suspended?
}

\author{
Rafael DENADAI, Fábio Vieira TEIXEIRA and Rogério SAAD-HOSSNE
}

\begin{abstract}
Context - Several paradoxical cases of infliximab-induced or-exacerbated psoriatic lesions have been described in the recent years. There is disagreement regarding the need to discontinue infliximab in order to achieve the resolution of these adverse cutaneous reactions specifically in inflammatory bowel disease (IBD) patients. Objective - To systematically review the literature to collect information on IBD patients that showed this adverse cutaneous reaction, focusing mainly on the therapeutic approach. Methods - A systematic literature review was performed utilizing Medline, Embase, SciELO and Lilacs databases. Published studies were identified, reviewed and the data were extracted. Results - Thirty-four studies (69 IBD patients) met inclusion criteria for review. There was inconsistency in reporting of some clinical and therapeutic aspects. Most patients included had Crohn's disease $(89.86 \%)$, was female $(47.83 \%)$, had an average age of 27.11 years, and no reported history of psoriasis $(84.05 \%)$. The patients developed primarily plaque-type psoriasis $(40.58 \%$ ). There was complete remission of psoriatic lesions in $86.96 \%$ of IBD patients, existing differences in the therapeutic approaches; cessation of infliximab therapy led to resolution in $47.83 \%$ of cases and $43.48 \%$ of patients were able to continue infliximab therapy. Conclusion - As increasing numbers of IBD patients with psoriasis induced or exacerbated by infliximab, physicians should be aware of its clinical manifestations so that appropriate diagnosis and treatment are properly established. The decision whether to continue or discontinue infliximab should be individualized.
\end{abstract}

HEADINGS - Inflammatory bowel disease. Infliximab. Psoriasis. Biological therapy.

\section{INTRODUCTION}

Infliximab is a chimeric IgG1 monoclonal antibody ( $75 \%$ human and $25 \%$ murine) that inhibits the tumor necrosis factor-alpha (anti-TNF- $\alpha$ ). It has been efficient in the treatment of inflammatory bowel diseases (IBD) for more than a decade ${ }^{(20)}$; however, since 2004, the number of paradoxical cases of psoriasis induced or exacerbated by infliximab described in IBD patients have increased ${ }^{(6,10,14,32,37)}$, since TNF- $\alpha$ inhibition determines therapeutic benefits in psoriasis ${ }^{(4)}$.

With this regard, there is disagreement in the literature as to the need to suspend biological therapy in order to achieve complete resolution of these cutaneous lesions (psoriasis), specifically in IBD patients. Some authors $^{(6,14)}$ agree to its withdrawal while others ${ }^{(10,32,37)}$ report that the biological must be maintained.

Due to risk for IBD deterioration after suspension of the TNF- $\alpha$ inhibitory molecule, the authors of the present study aimed at presenting a systematic litera- ture review on this intriguing phenomenon (psoriasis induced or exacerbated by infliximab) specifically in patients with IBD, mainly focusing on its therapeutic aspects.

\section{METHODS}

\section{Search strategy}

A systematic literature review was performed using the Medline (PubMed), Embase, SciELO and Lilacs databases from January 2004 to September 2011 so as to collect all relevant articles in English specifically addressing IBD patients who developed psoriasis after receiving infliximab by searching up the following terms "anti-TNF- $\alpha$ ", "biological", "Crohn" "inflammatory bowel disease", "infliximab", "TNF inhibitor", "tumor necrosis factor alpha inhibitor" and "ulcerative colitis" combined with terms "adverse event", "exacerbated", "guttate", "new-onset", "plaque", "pustular" and "psoriasis".

\footnotetext{
Research performed at Division of Coloproctology, Department of Surgery, School of Medical Sciences, State University of São Paulo (UNESP), Botucatu, SP, Brazil. Sources of funding: none.

Conflict of interest: The authors declare that they have no conflict of interest.

Division of Coloproctology, Department of Surgery, Botucatu Medical School, University of the State of São Paulo (UNESP), Botucatu, SP, Brazil.

Correspondence: Dr. Rafael Denadai - Paula Fabiana Tudela, 161 - Esmeralda - 17516-707 - Marília, SP, Brazil. E-mail: silva.rdp@hotmail.com
} 


\section{Study selection, data extraction and analysis}

The identified studies were selected for analysis based on their titles and abstracts whenever they were available. The studies that did not contain specific information on IBD patients who developed psoriasis during infliximab therapy were excluded. Each study included was individually reviewed in order to collect data concerning age, gender, personal and family history of psoriasis, biological medication administered, clinical latency, cutaneous lesion type, cutaneous biopsy performance, therapeutic approaches and outcomes. Two authors were responsible for data extraction independently and disagreements were resolved by consensus. Considering that such information does not provide sufficient data evidence or meta-analysis data, a critical and descriptive analysis was performed.

TABLE 1 . Summary of data on 69 inflammatory bowel disease patients who developed psoriasis after administration of infliximab published until September 2011

\begin{tabular}{|c|c|}
\hline Characteristics & Patients $(n=69)$ \\
\hline \multicolumn{2}{|l|}{ Primary disease, $\mathrm{n}(\%)$} \\
\hline $\mathrm{CD}$ & $62(89.86)$ \\
\hline UC & $5.0(7.25)$ \\
\hline $\mathrm{IBD} *$ & $2.0(2.89)$ \\
\hline \multicolumn{2}{|l|}{ Gender, n (\%) } \\
\hline Female & $33(47.83)$ \\
\hline Male & $32(46.38)$ \\
\hline Unknown & $4.0(5.80)$ \\
\hline Median age (years) & $27.11(8-54)$ \\
\hline Unknown, n (\%) & $6.0(8.70)$ \\
\hline \multicolumn{2}{|l|}{ Previous history of PS, n (\%) } \\
\hline No (de novo or induced PS) & $58(84.05)$ \\
\hline Personal (exacerbated pre-existing PS) & $3.0(4.35)$ \\
\hline Familiar & $4.0(5.80)$ \\
\hline Unknown & $4.0(5.80)$ \\
\hline Clinical latency (months) & $14.15(0.5-42)$ \\
\hline Unknown $* *, \mathrm{n}(\%)$ & $3.0(4.35)$ \\
\hline \multicolumn{2}{|l|}{ Type of skin lesion, n (\%) } \\
\hline Plaque-type PS & $28(40.58)$ \\
\hline Pustular-type PS & $6.0(8.70)$ \\
\hline Psoriasiform lesions & $5.0(7.25)$ \\
\hline More than one form of PS & $6.0(8.70)$ \\
\hline Guttate-type PS & $2.0(2.90)$ \\
\hline Diffuse-type PS & $2.0(2.90)$ \\
\hline Other & $6.0(8.70)$ \\
\hline Unknown & $14(20.29)$ \\
\hline
\end{tabular}

$\mathrm{UC}=$ ulcerative colitis;

$\mathrm{CD}=$ Crohn disease

$\mathrm{IBD}=$ inflammatory bowel disease;

PS = Psoriasis;

* = Ulcerative colitis or Crohn disease;

** = Some studies have reported only the number of doses administered

\section{RESULTS}

In the evaluated period and based on the previously described reviewing methodology, 69 patients with psoriasis induced or exacerbated during IBD therapy were found $^{(1-3,5,7-9,11,12,15-18,21-23,25-31,33-36,38-44)}$. The cases were described in 34 publications (33 peer-reviewed and one abstract of congress). Some information, such as gender, age, latency time between infliximab administration and the onset of psoriasis, cutaneous biopsy performance, therapeutic approach and clinical outcomes, was not described in all studies. A summary with the main demographic and clinical characteristics of the 69 IBD patients found is included in Table 1.

\section{Demographics}

Most of the patients who developed psoriasis received infliximab in order to control Crohn's disease $(89.86 \%)$. They were females $(47.83 \%)$, with a mean age of 27.11 years and did not report a personal and/or family history of psoriasis $(84.05 \%)$. In three patients, pre-existing psoriasis was exacerbated $^{(25,26)}$, and in three others, there was a positive family history of psoriasis ${ }^{(12,29,30)}$.

TABLE 2. Summary of therapeutic approaches and clinical outcomes in the 69 inflammatory bowel disease patients who developed psoriasis after administration of infliximab published until September 2011

\begin{tabular}{lc}
\hline Management & $\begin{array}{c}\text { Patients } \\
(\mathbf{n}=69)\end{array}$ \\
\hline Antipsoriatic therapy * $\mathbf{n}(\%)$ & $51(73.91)$ \\
Topical corticosteroid & $7.0(10.14)$ \\
Phototherapy & $4.0(5.78)$ \\
SCE & $3.0(4.35)$ \\
Metotrexato & $2.0(2.90)$ \\
SCE + AZA & $2.0(2.90)$ \\
Cyclosporine & $1.0(1.45)$ \\
MM + AZA & $1.0(1.45)$ \\
6-Mercaptopurine & $11(15.94)$ \\
Unknown & \\
IFX stopped, $\mathbf{n}(\%)$ & $35(50.72)$ \\
Yes & $30(43.48)$ \\
No & $4.0(5.78)$ \\
Unknown & \\
Clinical outcomes related to IFX, $\mathbf{n}(\%)$ & \\
Completely resolved off IFX & $33(47.83)$ \\
Partially resolved off IFX & - \\
No resolution off IFX & $2.0(2.90)$ \\
Completely resolved on IFX & $27(39.13)$ \\
Partially resolved on IFX & $3.0(4.35)$ \\
No resolution on IFX & - \\
\hline AZA = azathioprine; & \\
MFX = infliximab; & \\
*CE = systemic corticosteroid; & \\
Isolated or associated & \\
\hline
\end{tabular}




\section{Biological therapy}

The mean time of clinical latency between the beginning of infliximab infusions and the onset of psoriasis was of 14.15 months. In addition to infliximab, some patients also developed psoriasis with the administration of adalimumab ${ }^{(5,8,17)}$ and etanercept (used for associated spondyloarthritis) $)^{(5)}$.

\section{Clinical presentation}

Clinical presentation varied among the IBD patients who developed psoriasis during infliximab infusions, and there was predominance of plaque-type psoriasis $(40.58 \%)$, followed by the pustular type $(8.70 \%)$, and psoriasiform eruptions $(7.25 \%)$.

\section{Cutaneous biopsy}

In this review, the histopathological findings (lymphocytic infiltrate in the epidermis, epithelial hyperplasia with acanthosis and hyperkeratosis, parakeratosis, and dilated capillaries) in the 42 IBD patients submitted to cutaneous biopsy confirmed the clinical hypotheses of psoriasis $^{(1,2,7,23,27,34,38,39,41,44)}$.

\section{Treatment}

The majority of patients $(86.66 \%)$ showed complete remission of cutaneous lesions; however, therapeutic approaches varied (Table 2). Topical corticosteroids were the main anti-psoriatic therapy used (73.91\%). Infliximab was suspended, which resulted in psoriasis resolution in $47.83 \%$ of cases while cutaneous lesions receded even with subsequent infliximab infusions in $43.48 \%$ of cases.

\section{DISCUSSION}

Although the first case of infliximab-induced psoriasis was described in a 46-year old patient with Crohn's disease ${ }^{(42)}$, the majority $(73.91 \%)$ of subsequent reports have occurred in rheumatologic patients ${ }^{(6)}$. According to the present review, 69 cases $^{(1-3,5,7-9,11,12,15-18,21-23,25-31,33-36,38-44)}$ of psoriasis induced or exacerbated by infliximab were reported in IBD patients. Some studies ${ }^{(10,13,24,32,37,45)}$ did not participate in this descriptive analysis because it was not possible to extract data on IBD patients only under infliximab therapy and/or because they did not contain information on such patients' clinical development.

Regardless of the base disease, the cases of psoriasis induced or exacerbated by anti-TNF- $\alpha$ seem to predominate in females $(65 \%)$, at any age (mean of 44.9 years) and without a history of psoriasis $(85 \%)^{(6)}$, similarly to the IBD patients included in the present review. Also, without considering underlying diseases, the predominant form of psoriasis was the pustular type $(56 \%)^{(6)}$, which differs from the IBD patients in this and in other reviews including a smaller number of patients ${ }^{(6,14)}$, who primarily showed the plaque-type psoriasis.

The clinical latency period between anti-TNF- $\alpha$ administration and psoriasis development is extremely variable ${ }^{(6)}$. It is of 9.5 months in patients with different base diseases ${ }^{(7)}$ and of 14.15 months in the IBD patients presented in this review.
In other studies ${ }^{(6,7,14,44)}$ most cases were described in patients treated with infliximab (the object of this study). However, as there are cases involving different TNF- $\alpha$ inhibitors (infliximab, adalimumab, etanercept, and certolizumab ${ }^{(6,7,10,14,44)}$, such side effect has been described as a reaction to the pharmacological class, and not specifically to one $\operatorname{drug}^{(3,15,18)}$.

The pathogenesis of this paradoxical phenomenon (psoriasis subsequent to infliximab therapy) is still not completely known, and it is believed that plasmocytoid dendritic cells (natural IFN- $\alpha$ producers) are capable of inducing psoriasis through IFN- $\alpha$ production ${ }^{(6,18,22)}$. Since such plasmocytoid cells are usually downregulated by TNF- $\alpha$, its inhibition by the biological may determine increased and uncontrolled IFN- $\alpha$ production and consequently induce or exacerbate psoriasis $^{(6,18,22)}$.

Although in some patients, the diagnosis of psoriasis induced or exacerbated by infliximab was based only on the clinical aspect of cutaneous lesions, it has been described that patients must be evaluated by a dermatologist with the purpose to confirm the psoriasis hypothesis (correlating clinical manifestations with histopathological findings ${ }^{(35)}$ ) and discard similar cutaneous diseases (e.g., acute exanthematous pustulosis) and other psoriasis-triggering factors (e.g., infections and other medications) $)^{(6,7)}$.

In the literature, various therapeutic approaches have been described for the cases of psoriasis subsequent to infliximab administration. Regardless of the base disease, anti-TNF- $\alpha$ interruption or replacement culminated in the resolution of cutaneous lesions in $24 \%$ and $15 \%$ of cases, respectively ${ }^{(6,8)}$. In other reviews ${ }^{(6,14)}$, such strategy (interruption or replacement of the inhibitory molecule) has been more successful especially in IBD patients; resolution of cutaneous lesions after anti-TNF- $\alpha$ discontinuation was observed in $46 \%-88 \%$ of cases $^{(6,14)}$ while only $34 \%$ of patients showed resolution of cutaneous lesions without suspension of the biological ${ }^{(6)}$. However, these data must be cautiously interpreted because anti-TNF- $\alpha$ withdrawal can determine the aggravation of intestinal manifestations ${ }^{(3,8,17,31,38,40)}$.

Based on the present review ${ }^{(1,-3,5,7-9,11,12,15-18,21-23,25-31,33-36,38-44)}$, the IBD patients developing psoriasis during infliximab therapy must be treated by the conventional psoriasis approach (topical corticosteroids, phototherapy, vitamin-D analogs, methotrexate and/or cyclosporine) without the need to suspend infliximab. The discontinuation of infliximab infusions must be considered, especially in generalized, recalcitrant cases of psoriasis with important impact on quality of life. After the resolution of skin lesions, the reintroduction of biological therapy must be considered. In cases where it is necessary to suspend the biological, but IBD is aggressive, and infliximab withdrawal may lead to clinical deterioration, the adoption of alternative therapeutic forms (e.g., antibiotics, mesalazine, or azathioprine) for IBD control, or infliximab replacement for another inhibitory molecule must be considered. Although the administration of systemic corticosteroids has been used in some $\operatorname{cases}^{(2,23,41,44)}$, its introduction must be carefully analyzed due to the existing risk for psoriasis rebound ${ }^{(19)}$. 


\section{CONCLUSIONS}

As the number of IBD patients showing psoriasis after receiving infliximab increases, physicians dealing with such patients must be aware of their clinical manifestations so that an accurate diagnosis can be made and adequate therapy can be instituted. The decision about continuing or suspending biological therapy must be individualized and based on the response to the antipsoriatic approach (standard therapy), psoriasis severity, possibility of using alternative therapeutic forms for IBD and potential deleterious effect on IBD.

\section{ACKNOWLEDGEMENTS}

The authors thank the editorial suggestions by Dr. Ricardo Romiti and by Dr. Flavio Steinwurz concerning this manuscript.

Denadai R, Teixeira FV, Saad-Hossne R. Aparecimento de psoríase durante o tratamento das doenças inflamatórias intestinais com infliximabe: a terapia biológica deve ser suspensa? Arq Gastroenterol. 2012;49(2):172-6.

RESUMO - Contexto - Inúmeros casos paradoxais de lesões psoriásicas induzidas ou exacerbadas por infliximabe têm sido descritos nos últimos anos, existindo discordância quanto à necessidade de interromper o infliximabe, para se conseguir a resolução destas reações adversas cutâneas especificamente em pacientes com doença inflamatória intestinal (DII). Objetivo - Revisar sistematicamente a literatura para coletar informações sobre pacientes com DII, que apresentaram essa reação adversa cutânea, focando principalmente na abordagem terapêutica. Métodos - Uma revisão sistemática da literatura foi realizada utilizando as bases de dados Medline, Embase, SciELO e Lilacs. Os estudos publicados foram identificados, analisados e os dados extraídos. Resultados - Trinta e quatro estudos (69 pacientes com DII) preencheram os critérios de inclusão para a revisão, existindo inconsistência no relato de alguns aspectos clínicos e terapêuticos. A maioria dos pacientes incluídos tinha doença de Crohn ( $89,86 \%)$, era do sexo feminino (47,83\%), tinha idade média de 27,11 anos, e sem antecedentes de psoríase $(84,05 \%)$. Os pacientes desenvolveram principalmente a psoríase tipo placa $(40,58 \%$ ). Houve remissão completa das lesões psoriásicas em $86,96 \%$ dos pacientes com DII, existindo diferenças nas abordagens terapêuticas; interrupção do infliximabe determinou a resolução em 47,83\% dos casos e 43,48\% dos pacientes continuaram recebendo o tratamento com infliximabe. Conclusão - Uma vez que cresce o número de pacientes com DII com psoríase induzida ou agravada por infliximabe, os médicos devem estar cientes de suas manifestações clínicas, para que o diagnóstico e tratamento adequados sejam devidamente estabelecidos. A decisão sobre continuar ou interromper o infliximabe deve ser individualizada.

DESCRITORES - Doença inflamatória intestinal. Infliximabe. Psoríase. Terapia biológica. 


\section{REFERENCES}

1. Adams DR, Buckel T, Sceppa JA. Infliximab associated new-onset psoriasis. J Drugs Dermatol. 2006;5:178-9.

2. Angelucci E, Cocco A, Viscido A, Vernia P, Caprilli R. Another paradox in Crohn's disease: new onset of psoriasis in a patient receiving tumor necrosis factor-alpha antagonist. Inflamm Bowel Dis. 2007;13:1059-61.

3. Ávila-Alvarez A, García-Alonso L, Solar-Boga A, García-Silva J. Flexural psoriasis induced by infliximab and adalimumab in a patient with Crohn's disease. An Pediatr (Barc). 2009;70:278-81.

4. Barker J, Hoffmann M, Wozel G, Ortonne JP, Zheng H, van Hoogstraten H, Reich K. Efficacy and safety of infliximab vs. methotrexate in patients with moderate-to-severe plaque psoriasis: results of an open-label, active-controlled, randomized trial (RESTORE1). Br J Dermatol. 2011;165:1109-17.

5. Cohen JD, Bournerias I, Buffard V, Paufler A, Chevalier X, Bagot M, Claudepierre P. Psoriasis induced by tumor necrosis factor-alpha antagonist therapy: a case series. J Rheumatol. 2007;34:380-5.

6. Collamer AN, Battafarano DF. Psoriatic skin lesions induced by tumor necrosis factor antagonist therapy: clinical features and possible immunopathogenesis. Semin Arthritis Rheum. 2010;40:233-40.

7. Collamer AN, Guerrero KT, Henning JS, Battafarano DF. Psoriatic skin lesions induced by tumor necrosis factor antagonist therapy: a literature review and potential mechanisms of action. Arthritis Rheum. 2008;59:996-1001.

8. Conklin LS, Cohen B, Wilson L, Cuffari C, Oliva-Hemker M. Rash induced by anti-tumor necrosis factor agents in an adolescent with Crohn's disease. Nat Rev Gastroenterol Hepatol. 2010;7:174-7.

9. Costa-Romero M, Coto-Segura P, Suarez-Saavedra S, Ramos-Polo E, SantosJuanes J. Guttate psoriasis induced by infliximab in a child with Crohn's disease. Inflamm Bowel Dis. 2008;14:1462-3.

10. Cullen G, Kroshinsky D, Cheifetz AS, Korzenik JR. Psoriasis associated with antitumour necrosis factor therapy in inflammatory bowel disease: a new series and a review of 120 cases from the literature. Aliment Pharmacol Ther. 2011;34:1318-27.

11. Doyle LA, Sperling LC, Baksh S, Lackey J, Thomas B, Vleugels RA, Quresh AA, Velazquez EF. Psoriatic alopecia/alopecia areata-like reactions secondary to anti-tumor necrosis factor- $\alpha$ therapy: a novel cause of noncicatricial alopecia. Am J Dermatopathol. 2011;33:161-6.

12. English PL, Vender R. Occurrence of plantar pustular psoriasis during treatment with infliximab. J Cutan Med Surg. 2009;13:40-2.

13. Fidder H, Schnitzler F, Ferrante M, Noman M, Katsanos K, Segaert S, Henckaerts L, Van Asscge G, Vermeire S, Rutgeerts P. Long-term safety of infliximab for the treatment of inflammatory bowel disease: a single-centre cohort study. Gut 2009;58:501-8

14. Fiorino G, Allez M, Malesci A, Danese S. Review article: anti TNF-alpha induced psoriasis in patients with inflammatory bowel disease. Aliment Pharmacol Ther. 2009;29:921-7.

15. Goldstein J, Levine J. Infliximab-induced psoriaform rash. Clin Gastroenterol Hepatol. 2010;8:A24.

16. Hiremath G, Duffy L, Leibowitz I. Infliximab-induced psoriasis in children with inflammatory bowel disease. J Pediatr Gastroenterol Nutr. 2011;52:230-2.

17. Iborra M, Beltrán B, Bastida G, Aguas M, Nos P. Infliximab and adalimumabinduced psoriasis in Crohn's disease: a paradoxical side effect. J Crohns Colitis. 2011;5:157-61.

18. Laga AC, Vleugels RA, Qureshi AA, Velazquez EF. Histopathologic spectrum of psoriasiform skin reactions associated with tumor necrosis factor-alpha inhibitor therapy. A study of 16 biopsies. Am J Dermatopathol. 2010;32:568-73.

19. Lindgren S, Groth O. Generalized pustular psoriasis. A report on thirteen patients. Acta Derm Venereol. 1976;56:139-47.

20. Magro F, Portela F. Management of inflammatory bowel disease with infliximab and other anti-tumor necrosis factor alpha therapies. BioDrugs. 2010;24 Suppl $1: 3-14$

21. Manni E, Barachini P. Psoriasis induced by infliximab in a patient suffering from Crohn's disease. Int J Immunopathol Pharmacol. 2009;22:841-4.

22. Medkour F, Babai S, Chanteloup E, Buffard V, Delchier JC, Le-Louet H. Development of diffuse psoriasis with alopecia during treatment of Crohn's disease with infliximab. Gastroenterol Clin Biol. 2010;34:140-1.

23. Papadavid E, Gazi S, Dalamaga M, Stavrianeas N, Ntelis V. Palmoplantar and scalp psoriasis occurring during antitumour necrosis factor-alpha therapy: a case series of four patients and guidelines for management. J Eur Acad Dermatol Venereol. 2008;22:380-2.

24. Parian A, Scherl EJ, Kumar S, Taunk R, Green N, Lakehomer H, et al. Risk of developing anti-TNF alpha induced psoriasis among patients with Crohn's disease: are all anti-TNFS equal? Gastroenterology, 2010;138 Suppl 1:S672.
25. Park BC, Lim HJ, Kim BS, Lee WJ, Kim do W, Lee SJ. Repeated paradoxical aggravation of preexisting psoriasis during infliximab treatment for Crohn's disease. Ann Dermatol. 2009;21:60-2.

26. Passarini B, Infusino SD, Barbieri E, Varotti E, Gionchetti P, Rizzello F, Morselli C, Tambasco R, Campieri M. Cutaneous manifestations in inflammatory bowe diseases: eight cases of psoriasis induced by anti-tumor-necrosis-factor antibody therapy. Dermatology. 2007;215:295-300.

27. Peramiquel L, Puig L, Dalmau J, Ricart E, Roe E, Alomar A. Onset of flexural psoriasis during infliximab treatment for Crohn's disease. Clin Exp Dermatol. 2005;30:713-4.

28. Pérez-Pérez L, Caeiro JL, Fabeiro JM, Allegue F, Zulaica A. Induction of pustular lesions during infliximab therapy for Crohn's disease. Acta Derm Venereol. 2008;88:292-3.

29. Perman MJ, Lovell DJ, Denson LA, Farrell MK, Lucky AW. Five cases of anti-tumor necrosis factor alpha-induced psoriasis presenting with severe scalp involvement in children. Pediatr Dermatol. 2011 Oct 13. [Epub ahead of print] doi: 10.1111/j.1525-1470.2011.01521.x.

30. Pirard D, Arco D, Debrouckere V, Heenen M. Anti-tumor necrosis factor alpha-induced psoriasiform eruptions: three further cases and current overview. Dermatology. 2006;213:182-6.

31. Pourciau C, Shwayder T. Occurrence of pustular psoriasis after treatment of Crohn disease with infliximab. Pediatr Dermatol. 2010;27:539-40.

32. Rahier JF, Buche S, Peyrin-Biroulet L, Bouhnik Y, Duclos B, Louis E, Papay P, Allez M, Cosnes J, Cortot A, Laharie D, Reimund JM, Lémann M, Delaporte E, Colombel JF; Groupe d'Etude Thérapeutique des Affections Inflammatoires du Tube Digestif (GETAID). Severe skin lesions cause patients with inflammatory bowel disease to discontinue anti-tumor necrosis factor therapy. Clin Gastroenterol Hepatol. 2010;8:1048-55.

33. Richetta A, Mattozzi C, Carlomagno V, Maiani E, Carboni V, Giancristoforo S, D'Epiro S, Bruni F, Calvieri S. A case of infliximab-induced psoriasis. Dermatol Online J. 2008;14(11):9.

34. Seneschal J, Milpied B, Vergier B, Lepreux S, Schaeverbeke T, Taïeb A. Cytokine imbalance with increased production of interferon-alpha in psoriasiform eruptions associated with antitumour necrosis factor-alpha treatments. Br J Dermatol. 2009;161:1081-8.

35. Severs GA, Lawlor TH, Purcell SM, Adler DJ, Thompson R. Cutaneous adverse reaction to infliximab: report of psoriasis developing in 3 patients. Cutis. 2007;80:231-7.

36. Sherlock ME, Walters TD, Zachos M, Muise A, Griffiths AM. Infliximab-induced psoriasis in pediatric Crohn disease; experience of this paradoxical skin manifestation at a tertiary centre and a potential association with a variation in the IL-23r gene. Gastroenterology. 2009;136 Suppl 1:A671.

37. Shmidt E, Wetter DA, Ferguson SB, Pittelkow MR. Psoriasis and palmoplantar pustulosis associated with tumor necrosis factor- $\alpha$ inhibitors: the Mayo Clinic experience, 1998 to 2010. J Am Acad Dermatol. 2011 Jul 11. [Epub ahead of print] doi: 10.1016/j.jaad.2011.05.038.

38. Takahashi H, Hashimoto Y, Ishida-Yamamoto A, Ashida T, Kohgo Y, Iizuka H. Psoriasiform and pustular eruption induced by infliximab. J Dermatol. 2007;34:468-72.

39. Thurber M, Feasel A, Stroehlein J, Hymes SR. Pustular psoriasis induced by infliximab. J Drugs Dermatol. 2004;3:439-40.

40. Tichy M, Tichy M, Kopova R, Sternbersky J, Ditrichova D. Psoriasis and psoriatic arthritis induced in a patient treated with infliximab for Crohn's disease. J Dermato$\log$ Treat. 2011 Jan 22. [Epub ahead of print] doi: 10.3109/09546634.2010.521811.

41. Umeno J, Matsumoto T, Jo Y, Ichikawa M, Urabe K, Iida M. Psoriasis during anti-tumor necrosis factor-alpha therapy for Crohn's disease. Inflamm Bowel Dis. 2007;13:1188-9.

42. Verea MM, Del Pozo J, Yebra-Pimentel MT, Porta A, Fonseca E. Psoriasiform eruption induced by infliximab. Ann Pharmacother. 2004;38:54-7.

43. Wermuth J, Kind F, Steuerwald M. Palmoplantar pustulosis and acrodermatitis in a patient treated with infliximab for Crohn's sacroiliitis. Clin Gastroenterol Hepatol. 2009; 7:A28.

44. Wollina U, Hansel G, Koch A, Schönlebe J, Köstler E, Haroske G. Tumor necrosis factor-alpha inhibitor-induced psoriasis or psoriasiform exanthemata: first 120 cases from the literature including a series of six new patients. Am J Clin Dermatol. 2008;9:1-14.

45. Zabana Y, Domènech E, Mañosa M, Garcia-Planella E, Bernal I, Cabré E, Gassull MA. Infliximab safety profile and long-term applicability in inflammatory bowel disease: 9-year experience in clinical practice. Aliment Pharmacol Ther. 2010;31:553-60. 